\title{
Nitroblue tetrazolium test in experimental syphilis
}

\author{
VICTORIA WICHER, SANDRA BLAKOWSKI, AND KONRAD WICHER \\ From the Department of Microbiology, School of Medicine, SUNY at Buffalo, NY and Division \\ of Clinical Microbiology and Immunology, Erie County Laboratory, E. J. Meyer Memorial Hospital, \\ Buffalo, New York
}

SUMMARY The reduction of nitroblue tetrazolium (NBT) by phagocytic leucocytes in peripheral blood has been examined in rabbits injected intratesticularly with Treponema pallidum, $T$. pallidumfree supernatant of orchitic testes, or normal rabbit testes supernatant. A significant $(\mathbf{P}<0.01)$ increase in NBT reduction was observed only in the infected animals.

\section{Introduction}

The phenomena of phagocytosis and intracellular processing are primary and essential functions of host resistance to invading infectious agents. Phagocytosis is known to increase the reduction of nitroblue tetrazolium (NBT) by circulating phagocytic leucocytes (Baehner and Nathan, 1968; Park et al., 1968). The percentage of polymorphonuclear leucocytes spontaneously reducing NBT is elevated in most bacterial infections (Park et al., 1968; Feigin et al., 1971; Matula and Paterson, 1971) but there is no such information for experimental syphilis. It was therefore of interest to examine the changes and reactivity of rabbit peripheral blood leucocytes after infection with Treponema pallidum.

\section{Material and methods}

\section{ANIMALS}

Thirty New Zealand male rabbits, 3-4 kg each, were divided into three groups: 10 animals were infected intratesticularly (it) with $1 \mathrm{ml}$ of $2 \times 10^{7} T$. pallidum Nichols strain (TpS), 10 control animals were injected by the same route with $1 \mathrm{ml}$ of treponemafree supernatant (TFS), and a second control group (10 rabbits) was injected similarly with $1 \mathrm{ml}$ of normal rabbit testes supernatant (NRT). The TFS was prepared from the same orchitic testes used for infection of the first group by centrifuging the saline

Supported by grant AI-11102 from the National Institute of Health, United States Public Health Service

Address for reprints : Dr K. Wicher, Erie County Laboratory, Division of Clinical Microbiology, E. J. Meyer Hospital, 462 Grider Street, Buffalo, NY 14215, USA

Received for publication 29 April 1977 extract of the testes at $17000 \mathrm{rev} / \mathrm{min}$ for two hours and filtering the supernatant through a $0.22 \mathrm{~nm}$ Millipore filter. The infectivity of the TpS and TFS was tested by examining the testes for orchitis and by serological tests for cardiolipin (Venereal Disease Research Laboratory-VDRL) and treponemal antibodies (fluorescent treponemal antibody absorption FTA-ABS) test. For the NBT test, the total and differential white blood cell (WBC) count, and for serodiagnosis, all animals were bled before injectior and then every five to 10 days during a period of two months.

\section{NITROBLUE TETRAZOLIUM TEST}

Blood was drawn from the middle ear artery into sterile vacutainer tubes containing EDTA. Nitroblue tetrazolium, crystalline, grade III (Sigma Chemical Company, St Louis, Missouri) was dissolved in phosphate buffered saline (PBS), $\mathrm{pH} 7 \cdot 2$, to a final concentration of $0.2 \%$. One hundred microlitres of blood was mixed with an equal volume of NBT reagent in sterile plastic tubes, incubated for 30 minutes at $37^{\circ} \mathrm{C}$ in a water bath, and for 15 minutes at room temperature. The preparation was mixed gently before preparing films on clean glass slides. The films were air dried, fixed by gentle heat, and counterstained with $0.5 \%$ aqueous safranin 0 for two minutes. The slides were washed in water for two minutes and allowed to dry. The percentage of NBT-positive leucocytes (neutrophils and monocytes) was determined by counting 100-200 cells under oil immersion. Results were statistically analysed by the Wilcoxon matched-pairs signedranks test (Siegel, 1958).

ENDOTOXIN-STIMULATED NBT TEST

Lipopolysaccharide from Escherichia coli (Difco 
Laboratories, Inc., Detroit, Michigan), at a concentration of $100 \mu \mathrm{g} / \mathrm{ml}$, in PBS was used. One hundred microlitres of heparinised blood (20 units/ $\mathrm{ml})$ were mixed with $100 \mu l$ of endotoxin preparation and incubated for five minutes at room temperature before adding the NBT reagent and processing further as described above.

\section{Results}

Only the $T$. pallidum infected animals developed orchitis between 10-13 days after infection and demonstrated cardiolipin (VDRL) and treponemal (FTA-ABS) antibodies. The antibodies began to appear 12 days after infection and reached maximum titres between three (VDRL) and five (FTA-ABS) weeks. Animals in the control group injected with TFS did not demonstrate any morphologically visible changes in the testes nor did they produce detectable antibodies.

The total number of leucocytes examined in all animals before injection ranged from 4917 to 6683 (mean 5942). No significant variation in the total WBC count was observed in any of the three groups of animals during the two months of experiments. The differential counts of leucocytes from the infected animals showed a gradual increase (up to 50 days) although this was not significant in the relative and absolute number of neutrophils. No significant variation in the number of lymphocytes or neutrophils was seen in animals of either control group.

The results of the spontaneous NBT test are presented in the Table and expressed as a percentage of NBT positive cells with median and range values. The medians of the NBT positive leucocytes (neutrophils and monocytes) obtained from the 30 animals before injection ranged between 7.0 and $9.0 \%$. These values are in very close agreement with the NBT test done in a preliminary experiment using the peripheral blood of 50 normal rabbits of similar age and sex. The values in this normal group ranged from 1 to $15 \%$, with a median of $8.5 \%$. A significant $(P<0.01)$ increase in the NBT reduction was observed in the infected animals as early as 10 days after infection (range 15 to $36 \%$, median $20.5 \%$ ) and reached the highest values 30 days after infection (range 16 to $42 \%$, median $26.5 \%$ ). The increase in the NBT reduction was transient: most of the infected animals examined from 50 to 120 days after infection demonstrated values within the normal ranges. Forty endotoxin-stimulated NBT tests were done using heparinised blood from randomly selected animals from the infected and control groups at different times after injection. Much higher values and variations (range 28 to $72 \%$ ) were observed in all animals, regardless of whether the animals were infected or not.

No significant increase was observed in NBT reduction by the phagocytic cells in the animals injected with NRT. However, some animals of the control group injected with TFS showed an increase in NBT reduction with values slightly over the upper limit ( $>16)$ of normal animals. The results of the NBT reduction by leucocytes from the infected animals neither correlated with the symptoms of infection nor with the appearance of antibodies.

\section{Discussion}

The percentage of leucocytes (neutrophils and monocytes) undergoing spontaneous NBT reduction in peripheral blood of normal rabbits was found to be very similar to that reported in humans (Gordon et al., 1973). Endotoxin-stimulated leucocytes always gave higher values, regardless of whether the animals were normal or infected, indicating that the potential capability of the phagocytic cells is not impaired in syphilitic infection. A transient but significant increase in spontaneous NBT reduction by the peripheral leucocytes was observed in $T$. pallidum infected rabbits. The increase was observed as early as five days after infection (not presented in the Table) and was significantly elevated until the 40th day. The relationship between the NBT reduction and the host resistance to the infection is not clear at present. Enhancement of NBT reduction by polymorphonuclear cells has been clearly shown to be associated with the phagocytic process; by analogy, a rise in the number of active phagocytes has been reported during bacterial infection (Park et al., 1968; Feigin et al., 1971; Matula and Paterson, 1971; Gordon et al., 1973). Our findings indicate that syphilitic infection increases the metabolic activity of phagocytes. However, we are not certain whether this stimulation is related to the actual phagocytosis of the invading treponemes. Complement has been shown to display a similar effect in the absence of phagocytosis (Goldstein et al., 1975), but this does not seem to be the case in our experiments since the blood was drawn into EDTA which prevents activation of the complement system. Schell and Musher (1974) have found that $T$. pallidum infected rabbits demonstrated an increased listericidal activity between three and five weeks after infection. This finding is in agreement with the higher activity of the peripheral blood phagocytes observed in our experiments. On the other hand, phagocytosis and intracellular processing of treponemes must take place since humoral response to treponemal antigens is readily detected in rabbits two weeks after infection. Nevertheless, the controversy over whether this phagocytic 
Table Percentage of NBT positive cells in infected and control rabbits

\begin{tabular}{|c|c|c|c|c|c|c|c|c|}
\hline & \multirow[b]{2}{*}{ Rabbit no. } & \multirow[b]{2}{*}{ Pre-injection } & \multicolumn{6}{|c|}{ Days after injection } \\
\hline & & & 10 & 20 & 30 & 40 & 50 & 60 \\
\hline \multirow[t]{2}{*}{$\begin{array}{l}T . \text { pallidum } \\
\text { infected }\end{array}$} & $\begin{array}{l}503 \\
516 \\
517 \\
518 \\
520 \\
525 \\
532 \\
533 \\
534 \\
535\end{array}$ & $\begin{array}{r}12 \\
3 \\
7 \\
16 \\
10 \\
7 \\
4 \\
7 \\
9 \\
6\end{array}$ & $\begin{array}{l}36 \\
16 \\
15 \\
16 \\
28 \\
17 \\
25 \\
28 \\
21 \\
20\end{array}$ & $\begin{array}{l}25 \\
14 \\
16 \\
25 \\
22 \\
14 \\
27 \\
20 \\
28 \\
18\end{array}$ & $\begin{array}{l}35 \\
32 \\
16 \\
19 \\
32 \\
17 \\
24 \\
28 \\
42 \\
25\end{array}$ & $\begin{array}{r}27 \\
15 \\
8 \\
21 \\
28 \\
9 \\
17 \\
11 \\
22 \\
20\end{array}$ & $\begin{array}{r}7 \\
9 \\
11 \\
11 \\
26 \\
10 \\
6 \\
8 \\
14 \\
12\end{array}$ & $\begin{array}{r}9 \\
8 \\
19 \\
17 \\
11 \\
8 \\
8 \\
10 \\
9 \\
6\end{array}$ \\
\hline & $\begin{array}{l}\text { Median } \\
\text { Range }\end{array}$ & $\begin{array}{l}7 \cdot 0 \\
3-16\end{array}$ & $\begin{array}{l}20 \cdot 5 \\
15-36\end{array}$ & $\begin{array}{l}21 \cdot 0 \\
14-28\end{array}$ & $\begin{array}{l}26 \cdot 5 \\
16-42\end{array}$ & $\begin{array}{c}18 \cdot 5 \\
8-28\end{array}$ & $\begin{array}{c}10 \cdot 5 \\
6-26\end{array}$ & $\begin{array}{l}9 \cdot 0 \\
6-19\end{array}$ \\
\hline \multirow[t]{2}{*}{$\begin{array}{l}\text { Control } \\
\text { rabbits } \\
\text { injected } \\
\text { with NRT }\end{array}$} & $\begin{array}{l}\mathbf{5 5 0} \\
\mathbf{5 5 7} \\
\mathbf{5 8 7} \\
\mathbf{5 8 8} \\
\mathbf{5 8 9} \\
\mathbf{5 9 0} \\
\mathbf{5 9 1} \\
\mathbf{5 9 2} \\
\mathbf{5 9 3} \\
\mathbf{5 9 4}\end{array}$ & $\begin{array}{r}10 \\
11 \\
8 \\
9 \\
15 \\
5 \\
7 \\
7 \\
10 \\
4\end{array}$ & $\begin{array}{r}12 \\
12 \\
10 \\
12 \\
11 \\
13 \\
10 \\
10 \\
7 \\
8\end{array}$ & $\begin{array}{r}13 \\
13 \\
11 \\
9 \\
9 \\
8 \\
13 \\
10 \\
12 \\
10\end{array}$ & $\begin{array}{r}10 \\
9 \\
11 \\
9 \\
13 \\
11 \\
10 \\
14 \\
7 \\
12\end{array}$ & $\begin{array}{r}16 \\
14 \\
5 \\
9 \\
4 \\
7 \\
5 \\
6 \\
14 \\
3\end{array}$ & $\begin{array}{r}12 \\
12 \\
14 \\
9 \\
15 \\
6 \\
8 \\
5 \\
7 \\
5\end{array}$ & $\begin{array}{l}5 \\
8 \\
5 \\
7 \\
3 \\
6 \\
8 \\
8 \\
9 \\
3\end{array}$ \\
\hline & $\begin{array}{l}\text { Median } \\
\text { Range }\end{array}$ & $\begin{array}{l}8 \cdot 5 \\
4-15\end{array}$ & $\begin{array}{c}10 \cdot 5 \\
7-13\end{array}$ & $\begin{array}{c}10 \cdot 5 \\
8-13\end{array}$ & $\begin{array}{c}10 \cdot 5 \\
7-14\end{array}$ & $\begin{array}{l}6 \cdot 5 \\
3-16\end{array}$ & $\begin{array}{l}8 \cdot 0 \\
5-15\end{array}$ & $\begin{array}{l}6 \cdot 5 \\
3-9\end{array}$ \\
\hline $\begin{array}{l}\text { Control } \\
\text { rabbits } \\
\text { injected } \\
\text { with TFS }\end{array}$ & $\begin{array}{l}548 \\
554 \\
555 \\
556 \\
577 \\
578 \\
595 \\
596 \\
597 \\
598\end{array}$ & $\begin{array}{r}8 \\
8 \\
12 \\
7 \\
14 \\
6 \\
7 \\
11 \\
10 \\
10\end{array}$ & $\begin{array}{r}11 \\
6 \\
10 \\
8 \\
13 \\
9 \\
11 \\
13 \\
13 \\
6\end{array}$ & $\begin{array}{r}13 \\
13 \\
11 \\
9 \\
12 \\
14 \\
17 \\
8 \\
10 \\
16\end{array}$ & $\begin{array}{r}8 \\
16 \\
11 \\
9 \\
5 \\
13 \\
19 \\
6 \\
7 \\
12\end{array}$ & $\begin{array}{r}17 \\
12 \\
12 \\
8 \\
11 \\
8 \\
13 \\
9 \\
6 \\
16\end{array}$ & $\begin{array}{r}10 \\
5 \\
11 \\
9 \\
13 \\
7 \\
18 \\
8 \\
8 \\
17\end{array}$ & $\begin{array}{r}17 \\
2 \\
8 \\
6 \\
10 \\
5 \\
4 \\
11 \\
9 \\
4\end{array}$ \\
\hline & $\begin{array}{l}\text { Median } \\
\text { Range }\end{array}$ & $\begin{array}{l}9 \cdot 0 \\
6-14\end{array}$ & $\begin{array}{c}10 \cdot 5 \\
6-13\end{array}$ & $\begin{array}{l}12 \cdot 5 \\
8-17\end{array}$ & $\begin{array}{c}10 \cdot 0 \\
5-19\end{array}$ & $\begin{array}{c}11 \cdot 5 \\
6-17\end{array}$ & $\begin{array}{l}9 \cdot 5 \\
5-18\end{array}$ & $\begin{array}{l}7 \cdot 0 \\
2-17\end{array}$ \\
\hline
\end{tabular}

activity is effective against dead or virulent microorganisms is unresolved. Intracellular localisation of virulent $T$. pallidum in the infected tissue has been reported (Fitzgerald et al., 1975). This finding, however, is difficult to correlate with the widely accepted fact that virulent treponemes clear slowly from the circulation (Frazier et al., 1952). Blood of $T$. pallidum infected rabbits has been shown to be infective for several years after the disease has become asymptomatic (Frazier et al., 1952). In addition, two reports (Graves and Johnson, 1975; Schell et al., 1975) have indicated that the course of $T$. pallidum infection in rabbits previously injected with BCG is unaltered. The suggested 'selective failure' of the phagocytes in the $T$. pallidum infected host might explain the immune deviation observed in the early stage of the infection.

\section{References}

Baehner, R. L., and Nathan, D. G. (1968). Quantitative nitroblue tetrazolium test in chronic granulomatous disease. New England Journal of Medicine, 278, 971-976.

Feigin, R. D., Shackelford, P. G., Choi, S. C., Flake, K. K., Franklin, F. A., and Eisenberg, C. S. (1971). Nitroblue tetrazolium dye test as an aid in the differential diagnosis of febrile disorders. Journal of Pediatrics, 78, 230-237.
Fitzgerald, T. J., Miller, J. N., and Sykes, J. A. (1975). Treponema pallidum (Nichols strain) in tissue cultures; cellular attachment, entry, and survival. Infection and Immunity, 11, 1133-1140.

Frazier, C. N., Bensel, A., and Keuper, C. S. (1952). Further observations on the duration of spirochetemia in rabbits with asymptomatic syphilis. American Journal of Syphilis, Gonorrhea and Venereal Diseases, 36, 167-172.

Goldstein, I. M., Feit, F., and Weissmann, G. (1975). Enhancement of nitroblue tetrazolium dye reduction by leukocytes exposed to a component of complement in the absence of phagocytosis. Journal of Immunology, 114, 516-518.

Gordon, A. M., Rowan, R. M., Brown, T., and Carson, H. G. (1973). Routine application of the nitroblue tetrazolium test in the clinical laboratory. Journal of Clinical Pathology, 26, 52-56.

Graves, S. R., and Johnson, R. C. (1975). Effect of pretreatment with Mycobacterium bovis (strain BCG) and immune syphilitic serum on rabbit resistance to Treponema pallidum. Infection and Immunity, 12, 1029-1036.

Matula, G., and Paterson, P. Y. (1971). Spontaneous in vitro reduction of nitroblue tetrazolium by neutrophils of adult patients with bacterial infection. New England Journal of Medicine, 285, 311-317.

Park, B. H., Fikrig, S. M., and Smithwick, E. M. (1968). Infection and nitroblue tetrazolium reduction by neutrophils. A diagnostic aid. Lancet, 2, 532-534.

Schell, R. F., and Musher, D. M. (1974). Detection of nonspecific resistance to Listeria monocytogenes in rabbits infected with Treponema pallidum. Infection and Immunity, 9, 658-662.

Schell, R., Musher, D., Jacobson, K., Schwethelm, P., and Simmons, C. (1975). Effect of macrophage activation on infection with Treponema pallidum. Infection and Immunity, 12, 505-511.

Siegel, S. (1958). Nonparametric Statistics for the Behavioural Sciences, p. 75-83. McGraw-Hill: New York. 